Volume 1 Issue 2, July-December 2020: pp. 115-126.

Indonesian Private Law Review.

Fakultas Hukum, Universitas Lampung, Bandar Lampung, Indonesia.

P-ISSN: 2723-259X E-ISSN: 2745-9284

https://jurnal.fh.unila.ac.id/index.php/iplr

\title{
PENERAPAN PRINSIP TANGGUNG JAWAB MUTLAK (ABSOLUT LIABILITY) BERKAITAN DENGAN KERUGIAN KONSUMEN ATAS PENGGUNAAN PRODUK INTERNET BANKING
}

\section{THE IMPLEMENTATION OF ABSOLUT LIABILITY PRINCIPLES RELATED TO CONSUMER DAMAGES FOR THE USE OF INTERNET BANKING PRODUCTS}

\author{
Dian Mahardikha \\ Kantor Hukum Dian Mahardikha, S.H.,M.H. \&Partners \\ prayitnodian18@gmail.com
}

Submitted: October 1, 2020; Reviewed: October 14, 2020; Accepted: October 22, 2020

DOI: 10.2504l/iplr.vli2.2057

\begin{abstract}
Abstrak
Konsumen merupakan pihak yang berada dalam posisi lebih lemah apabila dibandingkan dengan pelaku usaha perbankan, sehingga konsumen tidak memiliki daya upaya untuk mendorong pelaku usaha perbankan untuk melakukan pemenuhan tanggung jawab atas timbulnya kerugian akibat penggunaan produk internet banking, hal tersebut menjadi salah satu alasan mengapa prinsip tanggung jawab mutlak (absolut liability) sangat penting untuk diterapkan. Penelitian ini memfokuskan pada permasalahan mengenai penerapan tanggung jawab mutlak (absolut liability) berkaitan dengan kerugian konsumen atas penggunaan produk internet banking, serta analisa terhadap faktor penghambat penerapan tanggung jawab mutlak (absolut liability) berkaitan dengan kerugian konsumen atas penggunaan produk internet banking. Metode yang digunakan dalam penelitian ini adalah penelitian hukum normatif empiris.

Hasil penelitian menunjukkan bahwa prinsip tanggung jawab mutlak (absolut liability) sulit untuk diterapkan apabila terdapat kerugian konsumen akibat penggunaan produk internet banking. Hal tersebut disebabkan karena Pasal 19 ayat (5) dan Pasal 28 Undang-Undang Perlindungan Konsumen serta Pasal 15 ayat (3) Undang-Undang Informasi dan Transaksi Elektronik mensyaratkan terpenuhinya unsur kesalahan pada pelaku usaha, sedangkan dalam prinsip tanggung jawab mutlak (absolut liability) unsur kesalahan pelaku usaha bukanlah merupakan syarat mutlak yang harus terpenuhi. Adapun faktor penghambat yang paling dominan terkait tidak dapat diterapkannya prinsip jawab mutlak (absolut liability) meliputi faktor perundang-undangan yaitu tidak adanya pengaturan tentang jawab mutlak (absolut liability), faktor penegak hukum yaitu adanya keterikatan sistem pembuktian pada unsur kesalahan pelaku usaha, dan faktor masyarakat selaku konsumen yaitu adanya keterbatasan untuk menuntut pemenuhan tanggung jawab kepada pelaku usaha.
\end{abstract}

Kata Kunci: Tanggungjawab, Mutlak, Kerugian, Produk. 


\begin{abstract}
Consumers are parties in weaker position than banking business actors, so consumers do not have the power to encourage banking business actors in fulfil their responsibility for losses in the use of internet banking products. This is one of the reasons why the absolut liability principle is very important to apply. This study focuses on issues regarding the implementation of absolut liability related to consumer losses from the use of internet banking products, as well as an analysis of the inhibiting factors of the implementation of absolut liability related to consumer losses from using internet banking products. The method in this research is empirical normative legal research.

The results study showed that the principle of absolut liability is difficult to apply if there are consumer losses due to the use of internet banking products. It is because Article 19 paragraph (5) and Article 28 of the Consumer Protection Law and Article 15 paragraph (3) of the Electronic Information and Transaction Law have requirements for the fulfillment of an element of error in a business actor, whereas in the principle of absolut liability the element of an actor's error business is not an absolute requirement that must be met. The most dominant factors related to the application of the principle of absolut liability can not include legal factors, namely the absence of absolut liability arrangements, law enforcement factors, namely the attachment of proof systems to the elements of business actors' mistakes, and community factors as consumers, namely the limitations to demand compliance responsibility to business actors.
\end{abstract}

Keywords: Absolut, Liability, Losses, Products.

\title{
A. Pendahuluan
}

Terdapat berbagai jenis pelayanan dalam transaksi perbankan seperti transfer, penarikan, kliring, setoran, dan lain lain. Transaksi tersebut kerap kali dilakukan secara manual oleh masyarakat dengan mendatangi bank langsung. ${ }^{1}$ Namun seiring dengan perkembangan teknologi informasi telah mendorong berkembangnya pelaksanaan transaksi perbankan secara online melalui internet atau yang lebih dikenal dengan layanan internet banking. ${ }^{2}$ Fasilitas layanan internet banking memberikan kemudahan bagi nasabah untuk untuk melakukan pembayaran-pembayaran secara online atau melalui internet. ${ }^{3}$ Internet banking dapat diakses oleh nasabah kapan dan dimana saja, sehingga mempermudah nasabah dalam bertransaksi seperti pembayaran tagihan, cek saldo, transfer, dan sebagainya. ${ }^{4}$ Hal tersebut banyak membantu pelayanan pada bank menjadi lebih cepat dan efektif serta. ${ }^{5}$

Berdasarkan data yang diperoleh dari website Bank Indonesia, diketahui bahwa jumlah transaksi internet banking pada akhir Desember 2018 mencapai 310.719 .605 (tiga ratus sepuluh juta tujuh ratus sembilan belas ribu enam ratus lima) transaksi dengan nilai nominal transaksi sebesar Rp. 5.889.162.000.000 (lima triliun delapan ratus delapan puluh sembilan

\footnotetext{
1 Decky Hendarsyah, "KEAMANAN LAYANAN INTERNET BANKING DALAM TRANSAKSI PERBANKAN," IQTISHADUNA: Jurnal Ilmiah Ekonomi Kita 1, no. 1 (2012): 12-33, 12, DOI: 10.46367/iqtishaduna.v1i1.2.

${ }^{2}$ Amin Wahyudi, "PENGGUNAAN TEKNOLOGI INFORMASI DI DUNIA BISNIS DAN PERBANKAN," Jurnal Akuntansi dan Sistem Teknologi Informasi 7, no. 1 (2012): 12-18, 12.

${ }^{3}$ Budi Hermana, "PENGUKURAN KUALITAS LAYANAN INTERNET BANKING," Jurnal Ilmiah Ekonomi Bisnis 15, no. 1 (2011): 47-57, 48.

${ }^{4}$ Rinda Hesti Kusumaningtyas, Elsy Rahajeng, "PERSEPSI NASABAH AKAN LAYANAN ATM DAN EBANKING DENGAN METODE TAM," STUDIA INFORMATIKA: JURNAL SISTEM INFORMASI 10, no. 2 (2017): 89-92, 90, DOI:10.15408/SIJSI.V10I2.7756.

5 Arga Satria Antasari, Kertahadi, Riyadi, "PENGARUH PENGGUNAAN INTERNET BANKING TERHADAP KEPUASAN NASABAH (STUDI PADA PT. BANK RAKYAT INDONESIA (PERSERO) TBK CABANG BONTANG)," Jurnal Administrasi Bisnis 1, no. 2 (2013): 1-9, 2.
} 
milyar seratus enam puluh dua juta rupiah). ${ }^{6}$ Intensitas penggunaan jasa perbankan melalui internet banking selain memberikan dampak positif berupa kemudahan dan efisiensi transaksi perbankan juga dapat menimbulkan risiko bagi nasabah berupa timbulnya kerugian yang disebabkan oleh kegagalan sistem internet banking maupun kejahatan elektronik (cybercrime). Meskipun internet banking menjanjikan berbagai kemudahan, namun terdapat pula resiko dalam penggunaan internet banking seperti terjadinya pelanggaran hukum terkait data pribadi yang tersebar melalui internet dan adanya resiko finansial karena ulah para pelaku kejahatan perbankan. ${ }^{7}$

Penyelenggaraan internet banking yang berbasis teknologi informasi beresiko penyalahgunaan pihak-pihak yang tidak bertanggung jawab. ${ }^{8}$ Adapun terdapat perlindungan hukum terhadap data pribadi nasabah ketika bertransaksi menggunakan internet banking yaitu Undang-Undang No. 11 Tahun 2008 tentang Elektronik, Undang-Undang Nomor 36 Tahun 1999 Tentang Telekomunikasi dan Undang-Undang Nomor 8 Tahun 1997 Tentang Dokumen Perusahaan. ${ }^{9}$ Adapun beberapa contoh kerugian nasabah selaku konsumen jasa perbankan akibat penggunaan internet banking yang dialami oleh nasabah perbankan, antara lain sebagai berikut :

1. Nasabah PT Bank Rakyat Indonesia yang melakukan transaksi pembayaran tiket pesawat melalui i-bangking BRI pada tanggal 3 November 2017, setelah 2 (dua) kali melakukan pembayaran transaksi tersebut dinyatakan gagal, akan tetapi saldo sebesar Rp.1.147.000 (satu juta seratus empat puluh tujuh ribu rupiah) hilang dari rekening. Setelah melapor kepada PT Bank Rakyat Indonesia Cabang Tanjung Karang sebanyak 3 (tiga) kali PT Bank Rakyat Indonesia belum bisa memastikan penyebab hilangnya uang nasabah tersebut. ${ }^{10}$

2. Rekening nasabah atas nama Didin Irianawati pada tanggal 25 Desember 2017 tercatat terdapat transaksi senilai Rp.87.654.321 (delapan puluh tujuh juta enam ratus lima puluh empat ribu tiga ratus dua puluh satu rupiah) Uang tersebut hilang dan diambil melalui internet banking BRI. Atas peristiwa tersebut, PT Bank Rakyat Indonesia menyimpulkan bahwa nasabah atas nama Didin Irianawati merupakan korban penipuan dengan modus pencurian data melalui panggilan telepon. ${ }^{11}$

3. Nasabah PT Bank Rakyat Indonesia Unit Ngadiluwih yang bernama Elvina uang tabungannya berkurang Rp. 500.000. (lima ratus ribu rupiah), hal tersebut diketahuinya melalui layanan mobile banking, nasabah menerima pesan singkat pada ponselnya yang berisi informasi telah terjadi transaksi debet pada hari Minggu 11 Maret 2018, padahal nasabah yang bersangkutan pada hari tersebut tidak menggunakan mobile banking sama sekali. $^{12}$

Berdasarkan contoh kasus tersebut, dapat diketahui bahwa keberadaan produk internet banking yang disediakan oleh pelaku usaha perbankan masih terdapat permasalahan yang dapat menimbulkan kerugian bagi nasabah selaku konsumen jasa perbankan. Hilangnya jumlah uang nasabah dalam rekening telah menunjukkan bahwa pelaku usaha tidak dapat memberikan jaminan atas keamanan, kenyamanan dan kemudahan dalam melakukan

\footnotetext{
${ }^{6} \mathrm{https} / / /$ www.bi.go.id/, diakses pada tanggal 23 Januari 2019.

7 Dwi Ayu Astrini, "PERLINDUNGAN HUKUM TERHADAP NASABAH BANK PENGGUNA INTERNET BANKING DARI ANCAMAN CYBERCRIME," LEX PRIVATUM 3, no. 1 (2015): 149-160, 149.

${ }^{8}$ Satrio Pradana Devanto, Munawar Kholil, "PERLINDUNGAN HUKUM NASABAH DALAM TRANSAKSI MELALUI INTERNET BANKING (STUDI DI PT BANK PEMBANGUNAN DAERAH JAWA TIMUR TBK.)", Jurnal Privat Law 6, no. 1 (2018): 143-153, 144

9 Anak Agung Gede Raitanaya Bhaswara, I Gusti Ayu Puspawati, Ni Putu Purwanti, "PERLINDUNGAN HUKUM DALAM PENYELENGGARAAN LAYANAN INTERNET BANKING ATAS DATA PRIBADI NASABAH PADA BANK RAKYAT INDONESIA CABANG KLUNGKUNG", Kertha Semaya : Journal Ilmu Hukum 3, no. 3 (2015): 1-5, 4.

${ }^{10} \mathrm{https}: / /$ lampung.tribunnews.com/, diakses pada tanggal 23 Januari 2019.

${ }^{11} \mathrm{https}: / /$ news.detik.com, diakses pada tanggal 23 Januari 2019.

$12 \mathrm{https}: / /$ regional.kompas.com/read/, diakses pada tanggal 23 Januari 2019.
} 
transaksi perbankan melalui produk internet banking, keadaan tersebut apabila tidak diimbangi dengan pemenuhan tanggung jawab oleh pelaku usaha perbankan akibat atas timbulnya kerugian yang dialami nasabah dalam penggunaan internet banking tentunya dapat berpotensi menimbulkan perselisihan antara nasabah dengan bank.

Perlindungan hukum nasabah yang menggunaka e-banking mendapatkan perlindungan hukum positif yang berlaku di Indonesia, baik terkait permasalahan hukum perdata, maupun hukum pidana. ${ }^{13}$ Pemenuhan tanggung jawab bagi pelaku usaha terhadap konsumen diatur dalam Pasal 19 Undang-Undang Nomor 8 Tahun 1991 tentang Perlindungan Konsumen (UUPK), khususnya dalam Pasal 19 ayat (1) UUPK yang menentukan pelaku usaha bertanggungjawab memberikan ganti rugi atas kerusakan, pencemaran, dan atau kerugian konsumen akibat mengkonsumsi barang dan atau jasa yang dihasilkan atau diperdagangkan. ${ }^{14}$ Adapun mengenai bentuk pemberian ganti rugi tersebut dipertegas dalam Pasal 19 ayat (2) UUPK yang menentukan ganti rugi sebagaimana dimaksud pada ayat (1) dapat berupa pengembalian uang atau penggantian barang dan/atau jasa yang sejenis atau setara nilainya, atau perawatan kesehatan dan/atau pemberian santunan yang sesuai dengan ketentuan peraturan perundang-undangan yang berlaku. ${ }^{15}$ Pemenuhan tanggung jawab dalam ketentuan tersebut dapat dipahami sebagai bentuk tanggung jawab produk.

Pemenuhan tanggung jawab produk dalam hal terjadinya kerugian yang dialami oleh nasabah selaku konsumen jasa perbankan sebagaimana contoh kasus diatas menurut penulis hal tersebut dinilai tidak memberikan perlindungan hukum bagi nasabah, sebab apabila mencermati ketentuan Pasal 19 ayat (5) UUPK secara tegas disebutkan bahwa ketentuan sebagaimana dimaksud pada ayat (1) dan ayat (2) tidak berlaku apabila pelaku usaha dapat membuktikan bahwa kesalahan tersebut merupakan kesalahan konsumen. Dengan demikian dapat dipahami bahwa pemenuhan tanggung jawab atas timbulnya kerugian konsumen akibat penggunaan internet banking sangat bergantung pada terpenuhinya unsur kesalahan pada pelaku usaha perbankan.

Mendasar pada contoh kasus kerugian konsumen tersebut diatas, sudah selayaknya apabila pelaku usaha perbankan memberikan tanggung jawab berupa pemenuhan ganti kerugian secara langsung kepada konsumen mengingat kerugian yang dialami oleh konsumen secara nyata akibat dari adanya kegagalan sistem transaksi yang dimiliki oleh pelaku usaha perbankan, sehingga pemenuhan unsur kesalahan sebagaimana disyaratkan dalam Pasal 19 ayat (5) UUPK dapat dikesampingkan demi terlaksananya perlindungan konsumen. Hal ini berdasarkan pada perlindungan hukum yang berkaitan dengan kepercayaan dan keamanan nasabah terhadap system e-banking, sehingga perlindungan hukum yang memadai sangat diperlukan. ${ }^{16}$

Penelitian ini akan memfokuskan permasalahan pada penerapan tanggung jawab mutlak (absolut liability) berkaitan dengan kerugian konsumen atas penggunaan produk internet banking, serta analisa terhadap faktor penghambat penerapan tanggung jawab mutlak (absolut liability) berkaitan dengan kerugian konsumen atas penggunaan produk internet banking. Jenis penelitian ini adalah penelitian hukum normatif-empiris yang mengkaji pada analisis mengenai implementasi pemenuhan tanggung jawab pelaku usaha atas timbulnya kerugian

\footnotetext{
${ }^{13}$ Aryani Witasari, Aris Setiono, "PERLINDUNGAN HUKUM PENGGUNA JASA ELECTRONIC BANKING (E-BANKING) DI TINJAU DARI PERSPEKTIF HUKUM PIDANA DI INDONESIA,” Jurnal Pembaharuan Hukum 2, no. 1 (2016): 126-137, 129, DOI: 10.26532/jph.v2i1.1422.

14 Soemardjono, Brodjo Soedjono, "HUKUM PERLINDUNGAN KONSUMEN DALAM TRANSAKSI KONSUMEN DI DUNIA MAYA TENTANG TANGGUNGJAWAB PRODUK," Ragam Penelitian Mesin 3, no. 2 (2014): 1-16, 5.

${ }^{15}$ Tami Rusli, "PENYELESAIAN SENGKETA ANTARA KONSUMEN DAN PELAKU USAHA MENURUT PERATURAN PERUNDANG-UNDANGAN,” Keadilan Progresif 3, no. 1 (2012): 87-102, 99.

${ }^{16}$ Wafiya Wafiya, "Perlindungan Hukum Bagi Nasabah Yang Mengalami Kerugian Dalam Transaksi Perbankan Melalui Internet," Kanun Jurnal Ilmu Hukum 14, no. 1 (2012): 37-52, 40.
} 
konsumen dengan tipe penelitian yang bersifat deskriptif.

\section{B. Pembahasan}

\section{Penerapan Tanggung Jawab Mutlak (Absolut Liability) Berkaitan dengan Kerugian Konsumen Atas Penggunaan Produk Internet Banking}

Kehadiran internet banking telah menawarkan sejumlah fleksibilitas dan kemudahan dalam melakukan transaksi perbankan, baik antara bank dengan nasabah, bank dengan bank maupun nasabah dengan nasabah. Disamping memberikan berbagai manfaat dan keunggulan, penggunaan internet banking dalam pelaksanaan kegiatan operasional bank terdapat pula risiko yang berpotensi menimbulkan kerugian, khususnya bagi nasabah selaku konsumen jasa perbankan. Melekatnya hak dan kewajiban antara nasabah selaku konsumen jasa perbankan dengan pelaku usaha perbankan yang didasarkan pada hubungan kontraktual maupun non kontraktual berkenaan dengan penggunaan internet banking pada prinsipnya telah melahirkan adanya suatu beban tanggung jawab khususnya bagi pelaku usaha perbankan sehubungan dengan timbulnya kerugian yang dialami oleh konsumen terkait dengan pelaksanaan hak dan kewajiban dimaksud.

Adanya jaminan bagi konsumen sebagaimana diatur dalam Pasal 7 huruf f UUPK yang menentukan bahwa kewajiban pelaku usaha adalah memberi kompensasi, ganti rugi dan/atau penggantian atas kerugian akibat penggunaan, pemakaian dan pemanfaatan barang dan/atau jasa yang diperdagangkan, maupun dalam Pasal 19 ayat (1) UUPK yang menentukan bahwa pelaku usaha bertanggungjawab memberikan ganti rugi atas kerusakan, pencemaran, dan atau kerugian konsumen akibat mengkonsumsi barang dan atau jasa yang dihasilkan atau diperdagangkan, maka diketahui bahwa konsepsi tanggung jawab yang dibebankan kepada pelaku usaha perbankan dapat diakomodir melalui pemberian ganti rugi atas timbulnya kerugian yang dialami nasabah khususnya terkait dengan penggunaan internet banking.

Ketentuan Pasal 19 ayat (1) UUPK tersebut secara yuridis dikonsepsikan sebagai bentuk tanggung jawab produk (product liability). Menurut penulis, tanggung jawab product liability pada dasarnya terdapat relevansi dengan ketentuan Pasal 1504 KUH Perdata yang menentukan bahwa "si penjual diwajibkan menanggung terhadap cacat tersembunyi pada barang yang dijual, yang membuat barang itu tak sanggup untuk pemakaian yang dimaksud, atau yang demikian mengurangi pemakaian itu sehingga, seandainya si pembeli mengetahui cacat itu, ia sama sekali tidak akan membeli barangnya, atau tidak akan membelinya selain dengan harga yang kurang". Mendasar pada ketentuan tersebut, maka diketahui bahwa pemenuhan tanggung jawab product liability yang dilakukan oleh pelaku usaha berlaku pula prinsip tanggung jawab absolut liability, sebab sekalipun timbulnya kerugian konsumen tidak dilakukan secara langsung oleh pelaku usaha, akan tetapi kerugian dimaksud timbul akibat dari barang maupun jasa yang diperdagangkan oleh pelaku usaha, maka pelaku usaha tetap memiliki kewajiban untuk bertanggungjawab atas kerugaian yang dialami konsumen.

Menurut RC Hobert sebagaimana dikutip oleh Ratna Artha Windari, absolut liability diterapkan karena pada saat proses produksi atau distribusi suatu barang dan jasa, posis konsumen cenderung kurang menguntungkan dalam pembuktian kesalahan saat proses tersebut. Sehingga prinsip ini memaksa produsen agar lebih hati-hati. ${ }^{17}$ Mendasar pada teori tersebut apabila dikaitkan dengan kerugian nasabah akibat penggunaan internet banking maka pemenuhan tanggung jawab mutlak (absolut liability) sangat relevan untuk diterapkan, sebab dalam konteks penggunaan internet banking, timbulnya kerugian konsumen seringkali disebabkan oleh faktor internal perbankan itu sendiri, hal tersebut sebagaimana ditegaskan

\footnotetext{
17 Ratna Artha Windari, "PERTANGGUNGJAWABAN MUTLAK (ABSOLUT LIABILITY) DALAM HUKUM PERLINDUNGAN KONSUMEN," Jurnal Komunikasi Hukum (JKH) 1, no. 1 (2015): 108-118, 114, DOI: $10.23887 /$ jkh.v1i1.5013.
} 
oleh Rini Yuliani dalam wawancara yang dilakukan penulis yang menerangkan bahwa resiko yang seringkali timbul dalam penggunaan internet banking antara lain berupa :

a. Pencurian data finansial dari database bank.

b. Terjadi pencurian identitas.

c. Terdapat ancaman atau serangan seperti penyadapan komunikasi internet dan virus.

d. Kegagalan sistem transaksi internet.

e. Terjadi transaksi yang dilakukan oleh pihak yang tidak berwenang sehingga menimbulkan kerugian finansial bagi nasabah. ${ }^{18}$

Adapun hak-hak konsumen juga dimuat dalam hukum internasional, yaitu dalam Resolusi PBB Nomor 39/248 Tahun 1985. Hak-hak tersebut terdiri dari: ${ }^{19}$

a. Hak bagi perlindungan kesehatan dan keamanan bagi konsumen.

b. Hak perlindungan kepentingan sosial dan ekonomi.

c. Hak ketersediaan informasi untuk konsumen.

d. Hak ganti rugi.

e. Hak konsumen untuk bebas membentuk organisasi dan hak kebebasan berpendapat bagi kepentingan konsumen.

Berkaitan dengan timbulnya kerugian konsumen atas penggunaan internet banking, terdapat sarana yang dapat ditempuh oleh konsumen guna meminta pemenuhan tanggung jawab kepada bank melalui mekanisme pengaduan baik secara lisan maupun tertulis sebagaimana diatur dalam Peraturan Otoritas Jasa Keuangan Nomor 1/POJK.07/2013 tentang Perlindungan Konsumen Sektor Jasa Keuangan dan Surat Edaran Otoritas Jasa Keuangan Nomor 02/SEOJK.07/2014 tentang Pelayanan Penyelesaian Pengaduan Konsumen pada Pelaku Usaha Jasa Keuangan. Meskipun demikian, pemenuhan tanggung jawab pelaku usaha perbankan atas kerugian yang dialami oleh konsumen masih memerlukan adanya pembuktian atas kebenaran timbulnya kerugian yang dialami oleh konsumen adalah akibat dari kesalahan atau kelalaian pelaku usaha perbankan. Dalam hal ini, apabila bank dapat membuktikan bahwa kerugian tersebut disebabkan karena kelalaian atau kesalahan konsumen maka bank tidak akan memberikan ganti rugi terhadap konsumen, hal tersebut selaras dengan ketentuan Pasal 19 ayat (1), ayat (2), ayat (5) UUPK, Pasal 19 UUPK.

Melekatnya unsur kesalahan pada pelaku usaha perbankan dalam ketentuan tersebut terkait dengan pemenuhan tanggung jawab atas kerugian yang dialami konsumen pada dasarnya sangat bertolak belakang dengan prinsip tanggung jawab mutlak (absolut liability). Diperlukan adanya prinsip tanggung jawab mutlak (absolut liability) adalah agar konsumen dapat menuntut kompensasi ketika suatu produk yang dibeli konsumen cacat atau tidak aman dan konsumen merasa dirugikan. ${ }^{20}$

Tidak diaturnya ketentuan mengenai tanggungjawab mutlak (absolut liability) dalam UUPK secara hukum telah membawa pada suatu keadaan bahwa pemenuhan tanggung jawab melalui pemberian ganti rugi oleh bank kepada konsumen dilaksanakan secara berlarut-larut, disamping itu tidak dimilikinya kemampuan bagi konsumen untuk membuktikan bahwa timbulnya kerugian atas penggunaan internet banking bukan karena kelalaian dan kesalahannya akibat keterbatasan akses untuk menelusuri aliran dana yang dimilikinya melalui jaringan internet tentunya berpotensi membawa kerugian yang semakin kompleks bagi konsumen, terlebih dalam ketentuan UUPK maupun Peraturan Otoritas Jasa Keuangan Nomor 1/POJK.07/2013 tentang Perlindungan Konsumen Sektor Jasa Keuangan dan Surat

\footnotetext{
${ }^{18}$ Wawancara dengan Rini Yuliani selaku Staff Legal pada Bank Rakyat Indonesia Cabang Metro pada tanggal 6 Mei 2019. $19 \mathrm{M}$. W. (Mohammad) Hamin, "PERLINDUNGAN HUKUM BAGI NASABAH (DEBITUR) BANK SEBAGAI KONSUMEN PENGGUNA JASA BANK TERHADAP RISIKO DALAM PERJANJIAN KREDIT BANK" Lex Crimen 6, no. 1 (2017): 46-53, 48.

${ }^{20}$ Ari Wahyudi Hertanto, "URGENSI PENGATURAN ABSOLUT LIABILITY DALAM RANCANGAN AMANDEMEN UNDANG-UNDANG PERLINDUNGAN KONSUMEN," Jurnal Hukum \& Pembangunan 41, no. 1 (March 3, 2011): 1-47, 5, DOI: 10.21143/jhp.vol41.no1.239.
} 
Edaran Otoritas Jasa Keuangan Nomor 02/SEOJK.07/2014 tentang Pelayanan Penyelesaian Pengaduan Konsumen pada Pelaku Usaha Jasa Keuangan telah menempatkan beban pembuktian kerugian konsumen kepada pihak bank sebagai pelaku usaha, hal tersebut tentunya dapat membuka peluang adanya itikad tidak baik dari pihak bank untuk secara sukarela memberikan ganti rugi serta lebih cenderung mencari kesalahan dan kelalaian konsumen agar dapat terhindar dari tuntutan pembayaran ganti rugi atas kerugian yang dialami konsumen.

Berdasarkan contoh kasus kerugian konsumen akibat penggunaan internet banking sebagaimana dikemukakan diatas, menurut analisis penulis penggunaan prinsip tanggung jawab mutlak (absolut liability) pada dasarnya ditujukan agar pelaku usaha perbankan bernarbenar memberikan perlindungan dan bertanggungjawab terhadap kepentingan konsumen. Dalam konteks ini, prinsip tanggung jawab mutlak (absolut liability) sangat penting untuk diterapkan karena yang seharusnya menanggung beban kerugian konsumen adalah pihak bank sebagai pelaku usaha yang menyediakan produk internet banking, sebab dengan adanya penyediaan produk tersebut maka secara hukum dapat diartikan bahwa bank telah menjamin produk tersebut aman untuk dipergunakan oleh konsumen. Disamping itu penerapan prinsip tanggung jawab mutlak (absolut liability) dapat meminimalisir timbulnya potensi kerugian yang semakin besar dialami oleh konsumen akibat berlarut-larutnya waktu pemenuhan tanggung jawab melalui pembayaran ganti rugi.

Meskipun Pasal 19 UUPK telah mengatur adanya tanggung jawab bagi pelaku usaha, akan tetapi penerapan ketentuan tersebut masih dapat membebaskan pelaku usaha perbankan dari kewajiban memberikan ganti rugi kepada nasabah, sebab ketentuan Pasal 19 UUPK menurut analisis penulis merupakan tanggung jawab yang berorientasi pada adanya kesalahan dengan mengadopsi Pasal 1365 KUHPerdata dan Pasal 1865 KUHPerdata. Dengan demikian maka diketahui bahwa pemenuhan tanggung jawab oleh bank atas kerugian yang dialami konsumen hanya dapat diterapkan jika bank benar-benar besalah dan memenuhi unsur kesalahan dalam pasal tersebut, apabila bank dapat membuktikan bahwa kesalahan disebabkan oleh konsumen maka resiko atau kerugian yang timbul menjadi tanggung jawab konsumen sendiri.

Menurut analisis penulis, penerapan prinsip tanggung jawab mutlak (absolut liability) atas timbulnya kerugian akibat penggunaan produk internet banking dapat dilaksanakan dengan mendasar pada ketentuan tanggung jawab tanpa kesalahan sebagaimana diatur dalam Pasal 1367 ayat (1) KUHPerdata. Diterapkannya konsep tanggung jawab mutlak (absolut liability) tanpa mengedepankan unsur kesalahan atas timbulnya kerugian akibat penggunaan internet banking secara yuridis dapat memenuhi tujuan perlindungan nasabah selaku konsumen jasa perbankan, yaitu memberikan kemudahan bagi konsumen untuk mempertahankan dan memperoleh apa yang menjadi hak nya berupa ganti kerugian dari pelaku usaha perbankan.

\section{Faktor Penghambat Penerapan Tanggung Jawab Mutlak (Absolut Liability) Berkaitan dengan Kerugian Konsumen Atas Penggunaan Produk Internet Banking}

Konsumen dituntut untuk sadar akan hak-haknya, sebagai control terhadap perbuatan dan perilaku pelaku usaha dan pemerintah. ${ }^{21}$ Melekatnya hak-hak konsumen dimaksud, khususnya hak untuk memperolah kompensasi, ganti rugi dan/atau penggantian atas timbulnya kerugian merupakan dasar bagi konsumen untuk menuntut pemenuhan tanggung jawab kepada pelaku usaha, sehingga dengan diakomodirnya hak konsumen dimaksud oleh pelaku usaha secara faktual dapat mendorong terciptanya perlindungan konsumen sebagaimana diamanatkan dalam UUPK.

Perlindungan konsumen pada dasarnya tidak dapat dipisahkan dengan kegiatan bisnis

\footnotetext{
${ }^{21}$ Holijah Holijah, "PENGINTEGRASIAN URGENSI DAN EKSISTENSI TANGGUNG JAWAB MUTLAK PRODUK BARANG CACAT TERSEMBUNYI PELAKU USAHA DALAM UNDANG-UNDANG PERLINDUNGAN KONSUMEN DI ERA GLOBALISASI,” Jurnal Dinamika Hukum 14, no. 1 (2014): 176-188, 181, DOI: 10.20884/1.JDH.2014.14.1.286.
} 
yang sehat dalam upaya pemenuhan kewajiban kepada pelaku usaha untuk selalu bertanggungjawab dalam hal terjadinya kerusakan, pencemaran dan atau kerugian atas penggunaan barang dan atau jasa yang diusahakan oleh pelaku usaha. ${ }^{22}$ Prinsip tanggung jawab pelaku usaha sebagaimana diatur dalam ketentuan UUPK adalah tanggung jawab produk (product liability) yang bersifat tanggung jawab mutlak (absolut liability), hal tersebut didasarkan pada adanya prinsip bahwa konsumen tidak memiliki kewajiban untuk membuktikan unsur kesalahan pada pelaku usaha yang menyebabkan kerugian akibat penggunaan barang dan atau jasa sebagai dasar pembayaran ganti kerugian. Meskipun tanggung jawab produk (product liability) dimaksud bersifat tanggung jawab mutlak (absolut liability), akan tetapi pemenuhan tanggung jawab yang dilakukan oleh pelaku usaha masih bergantung pada pembuktian tentang ada atau tidaknya kesalahan yang dilakukan oleh pelaku usaha atas barang dan atau jasa yang diperdagangkan.

Menurut Rini Yuliani dalam wawancara yang dilakukan penulis, menerangkan bahwa secara umum kerugian yang diderita oleh konsumen adalah berupa kerugian materiil yaitu kerugian yang secara nyata dialami oleh nasabah dalam bentuk nilai uang berkenaan dengan penggunaan internet banking, dengan demikian pemenuhan tanggung jawab yang dilakukan oleh bank terhadap konsumen didasarkan pada keadaan-keadaan sebagai berikut :

a. Apabila kerugian yang dialami disebabkan karena kesalahan dari konsumen pengguna internet banking itu sendiri, maka konsumen tidak dapat mengajukan tuntutan ganti kerugian kepada pihak bank karena kesalahan tersebut dilakukan oleh konsumen sendiri. Hal tersebut tidak mengharuskan bagi pihak bank untuk mengganti kerugian yang dialami oleh konsumen, tetapi pihak bank tetap membantu konsumen dalam mencari solusi atas kerugian yang dialaminya.

b. Sebaliknya, apabila ternyata kerugian yang diderita oleh konsumen disebabkan karena kesalahan dari pihak bank sebagai penyedia produk internet banking, maka pihak bank memiliki kewajiban untuk bertanggungjawab memberikan ganti rugi sesuai dengan kerugian yang dialami konsumen. Unsur kesalahan menjadi faktor penentu bagi pihak bank apakah terdapat kewajiban untuk melakukan tanggung jawab berupa memberikan ganti rugi kepada konsumen atau tidak. Apabila berdasarkan hasil investigasi yang dilakukan diketahui ternyata kerugian yang dialami oleh konsumen disebabkan karena kesalahan bank tentunya bank akan memberikan ganti kerugian, sebab prinsip pelaksanaan tanggung jawab untuk mengganti kerugian yang dialami oleh konsumen hanya dapat dilakukan apabila dapat dibuktikan adanya kesalahan yang dilakukan oleh pihak bank, hal tersebut didasarkan pada ketentuan Pasal 19 ayat (5) UUPK dan Pasal 15 ayat (3) Undang-Undang Informasi dan Transaksi Elektronik. ${ }^{23}$

Mendasar pada hasil penelitian tersebut, maka dapat dipahami bahwa penerapan tanggung jawab mutlak (absolut liability) dalam ruang lingkup pembayaran ganti rugi atas terjadinya kerugian konsumen akibat penggunaan internet banking sulit untuk diterapkan, hal tersebut disebabkan karena faktor dari UUPK yang belum mengakomodir pengaturan tanggung jawab mutlak (absolut liability) secara khusus, disamping itu hal tersebut juga dipengaruhi oleh faktor pelaku usaha yang lebih mengedepankan mekanisme pembuktian tentang ada atau tidaknya kesalahan yang dilakukannya terkait kerugian yang dialami oleh konsumen atas penggunaan internet banking. Mengacu pada contoh kasus hilangnya sejumlah uang milik nasabah selaku konsumen jasa perbankan akibat penggunaan internet banking sebagaimana telah dikemukakan diatas, maka diketahui bahwa sudah sepatutnya apabila pihak bank

\footnotetext{
${ }^{22}$ Anisa Nurlaila Sari, "LEGAL ANALYSIS OF DENTAL SERVICE RESPONSIBILITIES ACCORDING TO THE MINISTER OF HEALTH REGULATION NO. 39 OF 2014 CONCERNING DEVELOPMENT OF SUPERVISION AND LICENSING OF DENTAL WORKERS," Cepalo 2, no. 1 (2018): 21-32, 23, DOI: 10.25041/cepalo.v2no1.1759.

${ }^{23}$ Wawancara dengan Rini Yuliani selaku Staff Legal pada Bank Rakyat Indonesia Cabang Metro pada tanggal 6 Mei 2019.
} 
melakukan kewajibannya untuk memberikan tanggung jawab kepada konsumen, sebab sehubungan dengan kegiatan usaha yang dilakukan oleh pihak bank, apabila mencermati ketentuan Pasal 7 UUPK telah diatur secara jelas mengenai adanya kewajiban yang harus dilakukan.

Melekatnya kewajiban-kewajiban tersebut pada pelaku usaha perbankan, maka sangat relevan untuk dijadikan dasar tuntutan pemenuhan tanggung jawab atas timbulnya kerugian yang dialami oleh konsumen dalam hal penggunaan internet banking. Selanjutnya dengan mendasar pada kerugian konsumen sebagaimana contoh kasus diatas maka konsep tanggung jawab mutlak (absolut liability) sangat penting untuk diterapkan, sebab tedapat hubungan kausalitas antara timbulnya kerugian konsumen dengan penggunaan produk internet banking milik pelaku usaha perbankan, sehingga pemenuhan kewajiban tanggung jawab untuk mengganti kerugian yang dibebankan kepada pelaku usaha perbankan haruslah dipahami sebagai suatu kewajiban hukum itu sendiri. Adapun perbuatan yang dilakukan oleh pelaku usaha perbankan adalah dalam konteks adanya kelalaian atau kesalahan dalam penyediaan produk internet banking yang mengakibatkan kerugian bagi konsumen berupa hilangnya sejumlah uang dalam rekening konsumen pada bank dimaksud.

Berdasarkan penelitian yang dilakukan penulis, diketahui bahwa pelaku usaha perbankan tidak dapat melakukan pemenuhan tanggung jawab berupa pemberian ganti rugi secara langsung atas adanya kerugian konsumen akibat penggunaan internet banking, pemenuhan tanggung jawab hanya dapat dilaksanakan apabila terdapat bukti yang menunjukkan bahwa kerugian konsumen disebabkan oleh kelalaian atau kesalahan bank, dengan demikian dapat dipahami bahwa tanggung jawab mutlak (absolut liability) tidak dapat diterapkan dalam kasus tersebut, sebab prinsip dasar tanggung jawab mutlak (absolut liability) adalah tidak mempersoalkan mengenai ada atau tidak adanya kesalahan, tetapi pelaku usaha langsung bertanggungjawab atas kerugian yang ditimbulkan oleh produknya dengan dasar karena pelaku usaha yang kurang hati-hati serta adanya kewajiban untuk mencegah timbulnya kerugian lebih besar yang akan diderita konsumen.

Adanya hambatan penerapan tanggung jawab mutlak (absolut liability) atas timbulnya kerugian yang dialami oleh konsumen akibat penggunaan produk perbankan dalam jaringan (online) tersebut maka dapat dilakukan analisis dengan mendasar pada teori efektifitas sebagaimana dikemukakan oleh Soerjono Soekanto yang meliputi faktor perundang-undangan (substansi hukum), faktor penegak hukum, faktor sarana dan fasilitas, faktor masyarakat, serta faktor kebudayaan. ${ }^{24}$ Berdasarkan teori efektifitas tersebut, menurut analisis penulis faktor penghambat tidak dapat diterapkannya prinsip tanggung jawab multak (absolut liability) atas kerugian konsumen akibat penggunaan produk internet banking:

\section{Faktor perundang-undangan (substansi hukum)}

Prinsip tanggung jawab mutlak (absolut liability) menetapkan bahwa suatu tindakan dapat dimintakan pertanggungjawaban atas dasar adanya kerugian tanpa mempersoalkan ada atau tidaknya kelalaian maupun kesalahan. Dalam konteks tanggung jawab pelaku usaha atas timbulnya kerugian konsumen akibat penggunaan produk internet banking, prinsip dimaksud tidak diatur secara tegas dalam UUPK, meskipun terdapat pengaturan tentang tanggung jawab pelaku usaha untuk memberikan ganti rugi kepada konsumen akan tetapi hal tersebut tergantung pada adanya unsur kesalahan pelaku usaha sebagaimana diatur dalam Pasal 19 ayat (5) dan Pasal 28 UUPK, disamping itu terkait dengan tanggung jawab pelaku usaha atas penyediaan produk internet banking apabila ditinjau dari UU ITE pelaku usaha juga masih dapat membebaskan diri dari kewajiban untuk memberikan ganti rugi apabila kerugian yang dialami konsumen adalah kelalaian atau kesalahan konsumen itu sendiri, hal ini secara jelas diatur dalam Pasal 15 ayat (3) UU ITE.

\footnotetext{
${ }^{24}$ Soerjono Soekanto, Faktor-Faktor yang Mempengaruhi Penegakan Hukum (Rineka Cipta, Bandung, 1986), 8-11.
} 
Tidak adanya pengaturan tentang tanggung jawab mutlak (absolut liability) dalam UUPK, Undang-Undang Perbankan beserta peraturan pelaksananya maupun dalam UU ITE menjadi hambatan bagi konsumen untuk menuntut pemenuhan tanggung jawab mutlak (absolut liability) kepada pelaku usaha atas kerugian yang timbul akibat penggunaan internet banking. Disamping itu melekatnya pembuktian unsur kelalaian dan kesalahan dalam UUPK maupun UU ITE secara faktual bertentangan prinsip tanggung jawab mutlak (absolut liability) yang membebankan tanggung jawab kepada pelaku usaha tanpa harus melihat ada atau tidaknya unsur kelalaian maupun kesalahan.

\section{Faktor penegak hukum}

Keterlibatan penegak hukum dalam hal ini adalah Hakim selaku pejabat yang berwenang untuk mengadili penyelesaian sengketa perbankan berkenaan dengan produk internet banking memiliki peran yang strategis guna menerapkan prinsip tanggung jawab mutlak (absolut liability) atas kerugian yang dialami konsumen, akan tetapi Hakim selaku penegak hukum dalam menyelesaikan sengketa terikat pada ketentuan undang-undang sehingga tidak dapat lepas dari kententuan yang mengatur tentang penerapan tanggung jawab bagi pelaku usaha baik dalam UUPK maupun UU ITE. Keterikatan Hakim pada pembuktian unsur kesalahan sebagaimana diatur dalam Pasal 19 ayat (5) dan Pasal 28 UUPK serta Pasal 15 ayat (3) UU ITE mengakibatkan faktor penegak hukum juga menjadi salah satu hambatan tidak dapat diterapkannya prinsip tanggung jawab mutlak (absolut liability) untuk dibebankan kepada pelaku usaha atas timbulnya kerugian yang dialami konsumen.

\section{Faktor sarana dan fasilitas}

Pemenuhan tanggung jawab bergantung pada hasil investigasi internal yang dilakukan perusahaan sebagaimana telah diatur dalam Standar Operasional Prosedur (SOP) perusahaan perbankan, sehingga pelaku usaha perbankan tidak dapat secara serta merta memberikan pertanggungjawaban berupa pembayaran ganti kerugian terhadap semua pengaduan konsumen yang merasa mengalami kerugian akibat penggunaan produk internet banking melainkan terlebih dahulu harus dilakukan proses investigasi untuk membuktikan apakah kerugian dimaksud disebabkan oleh pihak bank atau pihak konsumen. Dengan demikian keberadaan Standar Operasional Prosedur (SOP) perusahaan perbankan yang mengatur tentang mekanisme pemenuhan tanggung jawab atas kerugian konsumen menjadi faktor penghambat tidak dapat diterapkannya prinsip tanggung jawab mutlak (absolut liability).

\section{Faktor masyarakat}

Keterbatasan pengetahuan maupun kemampuan masyarakat selaku konsumen jasa perbankan yang berada pada posisi lebih lemah dibandingkan pelaku usaha membawa pada kecenderungan untuk mengikuti pola yang diterapkan oleh pelaku usaha perbankan atas tuntutan ganti kerugian yang diajukannya, yang mana pelaku usaha perbankan lebih bersifat prosedural dan kaku dalam menyikapi tuntutan ganti rugi yang diajukan dengan mendasar pada proses pembuktian tentang ada atau tidaknya kesalahan walaupun secara faktual kerugian tersebut disebabkan oleh produk internet banking yang disediakan oleh pihak bank. Hal tersebut berdampak pada tidak dapat diterapkannya prinsip tanggung jawab mutlak (absolut liability) karena masyarakat selaku konsumen jasa perbankan tidak memiliki daya upaya untuk menuntut pelaku usaha perbankan untuk memberikan ganti rugi tanpa melalui proses pembuktian tentang ada atau tidaknya kesalahan yang dilakukan oleh pihak bank.

\section{Faktor kebudayaan}

Faktor kebudayaan yang dikonsepsikan dalam penelitian ini adalah mengenai adanya tindakan yang ditempuh secara terus-menerus sehingga menjadi suatu kebiasaan bagi pelaku 
usaha perbankan. Adapun kebiasan dimaksud adalah tindakan yang lebih mengedepankan pelaksanaan Standar Operasional Prosedur (SOP) khususnya dalam hal upaya pemenuhan tanggung jawab atas timbulnya kerugian konsumen, sehingga keberadaan Standar Operasional Prosedur (SOP) merupakan suatu hal yang harus diutamakan dibandingkan dengan penerapan prinsip tanggung jawab mutlak (absolut liability).

Mendasar pada faktor-faktor penghambat tersebut diatas, menurut analisis penulis faktor yang paling dominan memberikan pengaruh tidak dapat diterapkannya prinsip tanggung jawab mutlak (absolut liability) atas kerugian konsumen akibat penggunaan produk internet banking adalah faktor perundang-undangan (substansi hukum), faktor penegak hukum, dan faktor masyarakat selaku konsumen. Ketiga faktor tersebut merupakan faktor yang saling berkaitan antara satu dengan lainnya sehingga diperlukan suatu tindakan konkrit agar pelaksanaan prinsip tanggung jawab mutlak (absolut liability) terhadap pelaku usaha dapat diterapkan.

\section{Kesimpulan}

Penerapan prinsip tanggung jawab mutlak (absolut liability) kepada pelaku usaha perbankan atas timbulnya kerugian konsumen akibat penggunaan internet banking secara yuridis tidak dapat diterapkan, sebab ketentuan Pasal 19 ayat (5) dan Pasal 28 UndangUndang Perlindungan Konsumen (UUPK) maupun dalam Pasal 15 ayat (3) Undang-Undang Informasi dan Transaksi Elektronik (UU ITE) yang merupakan peraturan dasar pemenuhan tanggung jawab atas timbulnya kerugian konsumen tidak mengatur tentang prinsip tanggung jawab mutlak (absolut liability). Berkaitan dengan pemenuhan tanggung jawab, ketentuan tersebut mensyaratkan tentang terpenuhinya unsur kesalahan bagi pelaku usaha. Sedangkan esensi dalam tanggung jawab mutlak (absolut liability) adalah tidak mengenal adanya unsur kesalahan sehingga diperoleh simpulan bahwa terdapat pertentangan antara ketentuan peraturan tersebut dengan prinsip tanggung jawab mutlak (absolut liability). Faktor penghambat tidak dapat diterapkannya prinsip tanggung jawab mutlak(absolut liability) atas timbulnya kerugian konsumen akibat penggunaan produk perbankan dalam jaringan (online) disebabkan oleh beberapa faktor penghambat, antara lain: faktor peraturan perundangundangan (substansi hukum), faktor penegak hukum, faktor sarana dan fasilitas, faktor masyarakat, faktor kebudayaan.

\section{DAFTAR PUSTAKA}

\section{A. Jurnal}

Antasari, Arga Satria., Kertahadi., Riyadi. "PENGARUH PENGGUNAAN INTERNET BANKING TERHADAP KEPUASAN NASABAH (STUDI PADA PT. BANK RAKYAT INDONESIA (PERSERO) TBK CABANG BONTANG)," Jurnal Administrasi Bisnis 1, no. 2, 2013: 1-9.

Astrini, Dwi Ayu. "PERLINDUNGAN HUKUM TERHADAP NASABAH BANK PENGGUNA INTERNET BANKING DARI ANCAMAN CYBERCRIME." LEX PRIVATUM 3, no. 1, 2015: 149-160.

Bhaswara, Anak Agung Gede Raitanaya., Puspawati, I Gusti Ayu., Purwanti, Ni Putu. "PERLINDUNGAN HUKUM DALAM PENYELENGGARAAN LAYANAN INTERNET BANKING ATAS DATA PRIBADI NASABAH PADA BANK RAKYAT INDONESIA CABANG KLUNGKUNG", Kertha Semaya : Journal Ilmu Hukum 3, no. 3, 2015: 1-5.

Devanto, Satrio Pradana., Kholil, Munawar. "PERLINDUNGAN HUKUM NASABAH DALAM TRANSAKSI MELALUI INTERNET BANKING (STUDI DI PT BANK 
PEMBANGUNAN DAERAH JAWA TIMUR TBK.)", Jurnal Privat Law 6, no. 1, 2018: 143-153.

Hamin, M. W. (Mohammad). "PERLINDUNGAN HUKUM BAGI NASABAH (DEBITUR) BANK SEBAGAI KONSUMEN PENGGUNA JASA BANK TERHADAP RISIKO DALAM PERJANJIAN KREDIT BANK" Lex Crimen 6, no. 1, 2017: 46-53.

Hendarsyah, Decky. "Keamanan Layanan Internet Banking Dalam Transaksi Perbankan," IQTISHADUNA: Jurnal Ilmiah Ekonomi Kita 1, no. 1, 2012: 12-33, DOI: 10.46367/iqtishaduna.v1i1.2.

Hermana, Budi. "PENGUKURAN KUALITAS LAYANAN INTERNET BANKING." Jurnal Ilmiah Ekonomi Bisnis 15, no. 1, 2011: 47-57.

Kusumaningtyas, Rinda Hesti., Rahajeng, Elsy. "PERSEPSI NASABAH AKAN LAYANAN ATM DAN E-BANKING DENGAN METODE TAM," STUDIA INFORMATIKA: JURNAL SISTEM INFORMASI 10, no. 2, 2017: 89-92, DOI: 10.15408/SIJSI.V10I2.7756.

Rusli, Tami. "PENYELESAIAN SENGKETA ANTARA KONSUMEN DAN PELAKU USAHA MENURUT PERATURAN PERUNDANG-UNDANGAN," Keadilan Progresif 3, no. 1, 2012: 87-102.

Sari, Anisa Nurlaila. "LEGAL ANALYSIS OF DENTAL SERVICE RESPONSIBILITIES ACCORDING TO THE MINISTER OF HEALTH REGULATION NO. 39 OF 2014 CONCERNING DEVELOPMENT OF SUPERVISION AND LICENSING OF DENTAL WORKERS." Cepalo 2, no. 1, 2018: 21-32, DOI: 10.25041/cepalo.v2no1.1759.

Soemardjono., Soedjono, Brodjo. "HUKUM PERLINDUNGAN KONSUMEN DALAM TRANSAKSI KONSUMEN DI DUNIA MAYA TENTANG TANGGUNGJAWAB PRODUK." Ragam Penelitian Mesin 3, no. 2, 2014: 1-16.

Wafiya. "Perlindungan Hukum Bagi Nasabah Yang Mengalami Kerugian Dalam Transaksi Perbankan Melalui Internet," Kanun Jurnal Ilmu Hukum 14, no. 1, 2012: 37-52.

Wahyudi, Amin. "PENGGUNAAN TEKNOLOGI INFORMASI DI DUNIA BISNIS DAN PERBANKAN," Jurnal Akuntansi dan Sistem Teknologi Informasi 7, no. 1, 2012: 1218.

Windari, Ratna Artha. "PERTANGGUNGJAWABAN MUTLAK (ABSOLUT LIABILITY) DALAM HUKUM PERLINDUNGAN KONSUMEN.” Jurnal Komunikasi Hukum (JKH) 1, no. 1, 2015: 108-118, DOI: 10.23887/jkh.v1i1.5013.

Witasari, Aryani., Setiono, Aris. "PERLINDUNGAN HUKUM PENGGUNA JASA ELECTRONIC BANKING (E-BANKING) DI TINJAU DARI PERSPEKTIF HUKUM PIDANA DI INDONESIA." Jurnal Pembaharuan Hukum 2, no. 1, 2016: 126-137, DOI: $10.26532 /$ jph.v2i1.1422.

\section{B. Buku}

Muhammad, Abdulkadir. Hukum Perusahaan Indonesia. Bandung: Citra Aditya Bakti, 2006.

Soekanto, Soerjono. Faktor-Faktor yang Mempengaruhi Penegakan Hukum. Bandung: Rineka Cipta, 1986.

\section{Internet}

https://lampung.tribunnews.com/, diakses pada tanggal 23 Januari 2019. https://news.detik.com, diakses pada tanggal 23 Januari 2019.

https://regional.kompas.com/read/, diakses pada tanggal 23 Januari 2019.

https://www.bi.go.id/,diakses pada tanggal 23 Januari 2019. 